\title{
POŚTA
}

TELEKOMUNIKÁCIE A

ELEKTRONICKÝ OBCHOD

सीजिए:

\section{ÚROVEŇ POSKYTOVANIA POŠTOVÝCH ELEKTRONICKÝCH SLUŽIEB V OBLASTI EPOST}

\author{
Bystrík Nemček $^{1}$, Iveta Kremeňová ${ }^{2}$ Rita Tornyaiová $^{3}$
}

\section{Úvod}

Informačno-komunikačné technológie prudko zasiahli oblast' sociálnej a podnikovej komunikácie a majú značný podiel na poklese v oblasti listových zásielok. Ako reakciu na tento fakt prevádzkovatelia poštových služieb diverzifikujú a poskytujú nové elektronické služby svojim zákazníkom. Rozvoj digitálnej ekonomiky podmienil vznik potreby poštových podnikov k postupnej inovácii a rozvoju poštových elektronických služieb. Treba však zdôraznit', že tempo, rozsah a miera úspechu inovácie sú odlišné v závislosti od jednotlivých krajín, regiónov a trhov. Poštové elektronické služby majú celosvetovo rastúcu tendenciu, ale značný rozdiel nájdeme hlavne medzi rozvinutými a rozvojovými krajinami. V rámci celosvetového rozvoja existuje až 55 poštových elektronických služieb (PES). Pri otázke, či sa poštové elektronické služby považujú za strategicky dôležité vo vzt'ahu k budúcnosti poštového sektora existuje jednoznačná odpoved' - áno. Toto tvrdenie umocňuje aj štúdia svetovej poštovej únie (UPU), ktorá uskutočnila prieskum rozvoja poštových elektronických služieb vo viacerých krajinách.

\section{Klasifikácia poštových elektronických služieb}

Ako bolo zmienené v úvode existuje až 55 poštových elektronických služieb. Tieto služby sú zaradené do jednotlivých kategórií podl’a účelu danej služby. Kategorizácia služieb delí poštové elektronické služby do 4 základných oblastí. Sú to:

- ePost služby,

- eFinance služby,

- eCommerce služby,

- eGovernment služby.

Služby e-post zahŕňajú prístup na verejný internet na pobočkách pôšt, poštové elektronické mailboxy, on-line direct mail a i. Sú predmetom najväčšieho vývoja, obzvlášt' v rozvinutých krajinách. Sú nasledované elektronickými finančnými službami (eFinance), kde patria hlavne elektronická fakturácia, elektronické transakcie, on-line platba, e-fakturácie

\footnotetext{
${ }^{1}$ Ing. Bystrík Nemček., Žilinská univerzita v Žiline, Fakulta Prevádzky a ekonomiky dopravy a spojov, Katedra spojov, Univerzitná 1, 01026 Žilina, tel.: +4215133144, fax: +4215655615,

e-mail: bystrik.nemcek@fpedas.uniza.sk

${ }^{2}$ Doc. Ing. Iveta Kremeňová, PhD., Žilinská univerzita v Žiline, Fakulta Prevádzky a ekonomiky dopravy a spojov, Katedra spojov, Univerzitná 1, 01026 Žilina, tel.: +4215133144, fax: +4215655615 ,

e-mail: iveta.kremenova@fpedas.uniza.sk

${ }^{3}$ Ing. Rita Tornyaiová, Žilinská univerzita v Žiline, externá doktorandka na Fakulte Prevádzky a ekonomiky dopravy a spojov, Katedra spojov, Univerzitná 1, 01026 Žilina, fax: +4215655615,
} 
a podobne. Služby elektronického obchodu (eCommerce) zahŕňajú hlavne e-shop, kde sa uskutočňuje predaj poštových a filatelistických produktov, získanie SSL webových certifikátov a on-line predplatné časopisov. SSL certifikát je šifrovací kl’úč, ktorým sú chránené dáta proti zneužitiu tretími osobami. Strategicky dôležité sú aj služby v oblasti eGovernmentu, kde patria napr. digitálna totožnost', elektronické platby na dôchodkový systém, elektronické medicínske certifikáty. [1]

\subsection{Klasifikácia ePost služieb}

Tradičné poštové služby boli použité na ul'ahčenie komunikácie medzi občanmi a podnikmi prostredníctvom fyzických prostriedkov, ako sú listy. Služby ePost sú komunikačné služby poskytované zákazníkom s využitím informačno-komunikačných technológií. Nasledujúca tabul'ka klasifikuje jednotlivé ePost služby. [2]

Tabul'ka 1. Rozdelenie a charakteristika PES v rámci ePost

\begin{tabular}{|c|c|c|}
\hline Číslo & Názov služby & Charakteristika \\
\hline 1 & $\begin{array}{l}\text { Verejný prístup do } \\
\text { internetovej siete na } \\
\text { pobočkách pošty }\end{array}$ & Zákazníci majú prístup k internetovým službám na poštách. \\
\hline 2 & $\begin{array}{l}\text { Webové informácie } \\
\text { o službách a tarifách }\end{array}$ & $\begin{array}{l}\text { Zákazníci majú prístup k informáciám o rozličných službách } \\
\text { a produktoch ako aj príslušných tarifách a cenách na web stránke } \\
\text { pošty. }\end{array}$ \\
\hline 3 & Poštová email schránka & $\begin{array}{c}\text { Umožňuje zasielanie elektronických správ overeným odosielatel'om } \\
\text { a dodanie a uchovanie týchto správ a informácií pre overeného } \\
\text { adresáta. }\end{array}$ \\
\hline 4 & On-line direct mail & $\begin{array}{l}\text { Dodanie reklamy a iné formy marketingovej komunikácie poštou } \\
\text { prostredníctvom elektronických prostriedkov. }\end{array}$ \\
\hline 5 & $\begin{array}{l}\text { Poštou registrovaná } \\
\text { elektronická pošta }\end{array}$ & $\begin{array}{l}\text { Bezpečná poštová e-služba, ktorá poskytuje potvrdenie o odoslaní } \\
\text { a potvrdenie o doručení elektronickej správy a zabezpečený } \\
\text { komunikačný kanál overeným užívatel'om. }\end{array}$ \\
\hline 6 & Elektronická známka & $\begin{array}{l}\text { Poštovné, za ktoré sa dá elektronicky zaplatit’ alebo stiahnut' cez } \\
\text { poštovú web stránku alebo aplikáciu v smartphone. Poštovné je potom } \\
\text { fyzicky vytlačené alebo elektronicky uložené. Predstavuje doklad } \\
\text { predplatenej hodnoty poštových služieb. Obvykle poštové známky } \\
\text { majú formu čiarového kódu alebo formu RFID. }\end{array}$ \\
\hline 7 & $\begin{array}{l}\text { Elektronické známky na } \\
\text { mieru (personalizované) }\end{array}$ & $\begin{array}{c}\text { Elektronické známky navrhnuté na základe potrieb a požiadaviek } \\
\text { zákazníka. }\end{array}$ \\
\hline 8 & $\begin{array}{l}\text { Elektronická poštová } \\
\text { certifikačná značka }\end{array}$ & $\begin{array}{l}\text { Poskytuje evidentný doklad o elektronickej udalosti v danej forme, } \\
\text { v danom čase a obsahuje jednu alebo viac častí. }\end{array}$ \\
\hline 9 & Elektronický podpis & Poskytuje možnost' digitálneho podpisovania dokumentov \\
\hline 10 & E-telegram & $\begin{array}{l}\text { Poskytuje možnost' zostavit' telegram elektronicky, napr. e-mailom } \\
\text { alebo SMS a doručením príjemcovi fyzicky. }\end{array}$ \\
\hline 11 & E-pohl'adnica & $\begin{array}{l}\text { Poskytuje možnost' kúpit’ pohl'adnicu on-line, ktorá je potom doručená } \\
\text { príjemcom fyzicky alebo elektronicky. }\end{array}$ \\
\hline 12 & On-line úradný fax & $\begin{array}{l}\text { Umožňuje prenos textov a obrázkov, ktoré zodpovedajú originálu } \\
\text { prostredníctvom faxu. }\end{array}$ \\
\hline 13 & $\begin{array}{l}\text { Hybridný mail } \\
\text { (z elektronickej do } \\
\text { fyzickej podoby) }\end{array}$ & $\begin{array}{l}\text { Poskytuje zákazníkom možnost' odoslania originálnej správy, ktorá je } \\
\text { potom elektronicky spracovaná a skonvertovaná na listovú zásielku } \\
\text { pre fyzické doručenie adresátovi. }\end{array}$ \\
\hline
\end{tabular}




\begin{tabular}{|c|c|c|}
\hline 14 & $\begin{array}{l}\text { Hybridný mail } \\
\text { (z fyzickej do } \\
\text { elektronickej podoby) }\end{array}$ & $\begin{array}{c}\text { Poskytuje zákazníkom možnost’ zaslania originálnej správy vo fyzickej } \\
\text { podobe, ktorá je prevedená do elektronickej podoby a doručená } \\
\text { adresátovi. }\end{array}$ \\
\hline 15 & Vyhl'adávanie PSČ & $\begin{array}{c}\text { Umožňuje zákazníkom nájst' poštové smerovacie číslo v krajine, on- } \\
\text { line zadaním určitých informácií ako adresy, názvu spoločnosti alebo } \\
\text { mesta. }\end{array}$ \\
\hline 16 & $\begin{array}{l}\text { Overenie platnosti } \\
\text { poštovej adresy }\end{array}$ & $\begin{array}{l}\text { Umožňuje zákazníkom overit’ adresu on-line zadaním a konfrontovat' } \\
\text { ju tak s platnými adresami ulíc z databázy. }\end{array}$ \\
\hline 17 & $\begin{array}{l}\text { Vyhl'adávanie } \\
\text { umiestnenia pobočiek } \\
\text { pôšt }\end{array}$ & $\begin{array}{c}\text { Umožňuje zákazníkom vyhl'adávat' adresy pošty on-line zadaním } \\
\text { určitých informácií, ako sú ulice, mesto alebo PSČ. Zákazníci môžu } \\
\text { tiež získat' d'alšie informácie o rôznych produktoch a službách na } \\
\text { pošte, ako aj otváraciu dobu. }\end{array}$ \\
\hline 18 & Zmena adresy on-line & $\begin{array}{l}\text { Umožňuje zákazníkom zmenit’ ich mailovú adresu elektronicky, napr. } \\
\text { prostredníctvom internetového portálu. }\end{array}$ \\
\hline 19 & $\begin{array}{l}\text { Uchovávanie doručenej } \\
\text { pošty on-line }\end{array}$ & $\begin{array}{l}\text { Umožňuje zákazníkom požiadat' prostredníctvom e-mailu, on-line } \\
\text { aplikácie alebo telefónu pozastavenie doručovania pošty na ich adresu } \\
\text { a uloženie zásielky na určitú dobu. }\end{array}$ \\
\hline 20 & $\begin{array}{l}\text { Dohl'ad a monitorovanie } \\
\text { (T\&T) }\end{array}$ & $\begin{array}{c}\text { Umožňuje zákazníkom elektronický dohl'ad a monitorovanie poštovej } \\
\text { zásielky. }\end{array}$ \\
\hline 21 & $\begin{array}{l}\text { Elektronická notifikácia } \\
\text { pošte o zhromažd'ovaní } \\
\text { určitých list. zásielok }\end{array}$ & $\begin{array}{l}\text { Zákazníci majú možnost' oznámit' poštovému operátorovi elektronicky } \\
\text { žiadost' o zhromažd'ovaní listových zásielok so špecifickou adresou. }\end{array}$ \\
\hline 22 & $\begin{array}{l}\text { Elektronická notifikácia } \\
\text { adresátovi o doručení } \\
\text { listovej zásielky }\end{array}$ & $\begin{array}{l}\text { Pošta oznámi adresátovi elektronicky, že listová zásielka bude } \\
\text { doručená na požadovanú adresu. }\end{array}$ \\
\hline 23 & $\begin{array}{c}\text { Elektronická notifikácia } \\
\text { odosielatel'ovi o doručení } \\
\text { listovej zásielky }\end{array}$ & Elektronická notifikácia odosielatel’ovi o doručení listovej zásielky. \\
\hline 24 & $\begin{array}{l}\text { Elektronická notifikácia } \\
\text { pošte o zhromažd'ovaní } \\
\text { určitých balík. zásielkách }\end{array}$ & $\begin{array}{l}\text { Zákazníci majú možnost' oznámit' poštovému operátorovi elektronicky } \\
\text { žiadost' o zhromažd'ovaní balíkových zásielok so špecifickou adresou. }\end{array}$ \\
\hline 25 & $\begin{array}{l}\text { Elektronická notifikácia } \\
\text { adresátovi o doručení } \\
\text { balík. zásielky }\end{array}$ & $\begin{array}{c}\text { Pošta oznámi adresátovi elektronicky (SMS alebo email), že balíková } \\
\text { zásielka bude doručená na požadovanú adresu. }\end{array}$ \\
\hline 26 & $\begin{array}{c}\text { Elektronická notifikácia } \\
\text { odosielatel'ovi o doručení } \\
\text { balíkovej zásielky }\end{array}$ & $\begin{array}{l}\text { Elektronická notifikácia odosielatel’ovi o doručení balíkovej zásielky } \\
\text { na požadovanú adresu. }\end{array}$ \\
\hline 27 & $\begin{array}{l}\text { Kontrola obsahu } \\
\text { P. O. boxov on-line }\end{array}$ & $\begin{array}{l}\text { Umožňuje zákazníkom kontrolu obsahu ich fyzických schránok } \\
\text { prijatím elektronickej verzie ich listov alebo elektronického oznámenia } \\
\text { z pošty o nových balíkových zásielkach. }\end{array}$ \\
\hline 28 & $\begin{array}{l}\text { Zákaznícka servis } \\
\text { a kontakt } \\
\text { prostredníctvom webu }\end{array}$ & $\begin{array}{l}\text { Umožňuje zákazníkom kontaktovat’ poštu elektronicky na získanie } \\
\text { informácií o službách a informáciách prostredníctvom web stránky, } \\
\text { emailu alebo telefónu. }\end{array}$ \\
\hline 29 & $\begin{array}{l}\text { Aplikácie na mobilných } \\
\text { zariadeniach }\end{array}$ & Služby poskytované poštou s využitím smartphone aplikácií. \\
\hline
\end{tabular}

Zdroj: Universal postal union. Measuring postal e-services development: a global perspecitve. 2012, [online]. [cit. 2012-10-18]. Dostupné na internete:

<http://www.upu.int/fileadmin/documentsFiles/activities/electronicServices/studyPostalEservicesEn.pdf> Vlastné spracovanie

\section{2. Úroven̆ poskytovania služieb ePost}


Na základe predchádzajúceho rozdelenia poštových elektronických služieb pre oblast' ePost bola realizovaná analýza úrovne poskytovania týchto jednotlivých služieb v Slovenskej republike a Pol'sku. V rámci tabul'ky 2 môžeme vidiet' úroveň poskytovania PES.

Tabul'ka 2. Poskytovanie PES v oblasti ePost v rámci SR a Pol'ska

\begin{tabular}{|c|c|c|c|}
\hline $\begin{array}{l}\text { Číslo } \\
\text { služby }\end{array}$ & Názov služby & 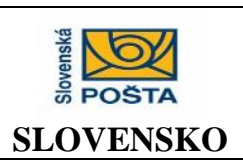 & $\begin{array}{c}\text { POCZTA POLSKA } \\
\text { POLSKO }\end{array}$ \\
\hline 1 & Verejný prístup do internetovej siete na pobočkách pošty & Nie & $\mathrm{Nie}$ \\
\hline 2 & Webové informácie o službách a tarifách & Áno & Áno \\
\hline 3 & Poštová email schránka & $\mathrm{Nie}$ & $\mathrm{Nie}$ \\
\hline 4 & On-line direct mail & $\mathrm{Nie}$ & $\mathrm{Nie}$ \\
\hline 5 & Poštou registrovaná elektronická pošta & Nie & $\mathrm{Nie}$ \\
\hline 6 & Elektronická známka & $\mathrm{Nie}$ & $\mathrm{Nie}$ \\
\hline 7 & Elektronické známky na mieru (personalizované) & Nie & Nie \\
\hline 8 & Elektronická poštová certifikačná značka & Nie & $\mathrm{Nie}$ \\
\hline 9 & Elektronický podpis & Áno & Nie \\
\hline 10 & E-telegram & $\mathrm{Nie}$ & Áno \\
\hline 11 & E-pohl'adnica & Nie & Nie \\
\hline 12 & On-line úradný fax & Nie & Nie \\
\hline 13 & Hybridný mail (z elektronickej do fyzickej podoby) & Áno & Áno \\
\hline 14 & Hybridný mail (z fyzickej do elektronickej podoby) & Áno & Nie \\
\hline 15 & Vyhl'adávanie PSČ & Áno & Áno \\
\hline 16 & Overenie platnosti poštovej adresy & Nie & Nie \\
\hline 17 & Vyhl’adávanie umiestnenia pobočiek pôšt & Áno & Áno \\
\hline 18 & Zmena adresy on-line & Nie & $\mathrm{Nie}$ \\
\hline 19 & Uchovávanie doručenej pošty on-line & Nie & $\mathrm{Nie}$ \\
\hline 20 & Dohl'ad a monitorovanie (T\&T) & Áno & Áno \\
\hline 21 & $\begin{array}{l}\text { Elektronic. notifikácia pošte o zhromažd’ovaní určitých } \\
\text { list. zásielok }\end{array}$ & Nie & Nie \\
\hline 22 & $\begin{array}{l}\text { Elektronická notifikácia adresátovi o doručení listovej } \\
\text { zásielky }\end{array}$ & Nie & $\mathrm{Nie}$ \\
\hline 23 & $\begin{array}{l}\text { Elektronická notifikácia odosielatel’ovi o doručení listovej } \\
\text { zásielky }\end{array}$ & Nie & $\mathrm{Nie}$ \\
\hline 24 & $\begin{array}{l}\text { Elektronická notifikácia pošte o zhromažd’ovaní určitých } \\
\text { balíkových zásielkách }\end{array}$ & Nie & Áno \\
\hline 25 & $\begin{array}{l}\text { Elektronická notifikácia adresátovi o doručení balíkovej } \\
\text { zásielky }\end{array}$ & Nie & Nie \\
\hline 26 & $\begin{array}{l}\text { Elektronická notifikácia odosielatel’ovi o doručení } \\
\text { balíkovej zásielky }\end{array}$ & Nie & Áno \\
\hline 27 & Kontrola obsahu P. O. boxov on-line & Nie & $\mathrm{Nie}$ \\
\hline 28 & Zákaznícka servis a kontakt prostredníctvom webu & Nie & Áno \\
\hline 29 & Aplikácie na mobilných zariadeniach & $\mathrm{Nie}$ & $\mathrm{Nie}$ \\
\hline
\end{tabular}


Zdroj: Universal postal union. Measuring postal e-services development: a global perspecitve. 2012, [online]. [cit. 2012-10-18]. Dostupné na internete:

〈http://www.upu.int/fileadmin/documentsFiles/activities/electronicServices/studyPostalEservicesEn.pdf > Vlastné spracovanie

Na základe realizovanej analýzy úrovne poskytovania PES v oblasti ePost je možné konštatovat', že Slovensko a ani Pol'sko nepatria medzi špičku v rámci poskytovania PES v oblasti ePost. Z 29 služieb špecifikovaných svetovou poštovou úniou realizuje Slovensko 7 a Pol'sko 9 služieb ePost.

\section{Rozvoj poštových elektronických služieb}

Poštové podniky musia nepretržite reagovat' na vzrastajúce potreby svojich zákazníkov a poskytovat' im nové poštové elektronické služby. Na obrázku 1 možno vidiet', že počet nových poštových elektronických služieb z globálneho hl'adiska ma rastúcu tendenciu. Je zrejmé, že táto činnost', pokial' ide o zavádzanie nových poštových elektronických služieb rastie exponenciálne. V roku 1996 bolo v celosvetovom meradle len okolo 5 služieb. V roku 2001 sa počet zvýšil niečo cez 20. V roku 2006 bolo zavedených 50 nových služieb. A v roku 2010 celková hodnota dosiahla 85 nových služieb. Tu je vidiet', že za štyri roky v období medzi 2007 a 2010 sa počet elektronických služieb takmer strojnásobil. Tento fakt je dôkazom toho, že pošty v rámci celého sveta zvyšujú svoje úsilie v súvislosti s novými službami na trhu. [1]

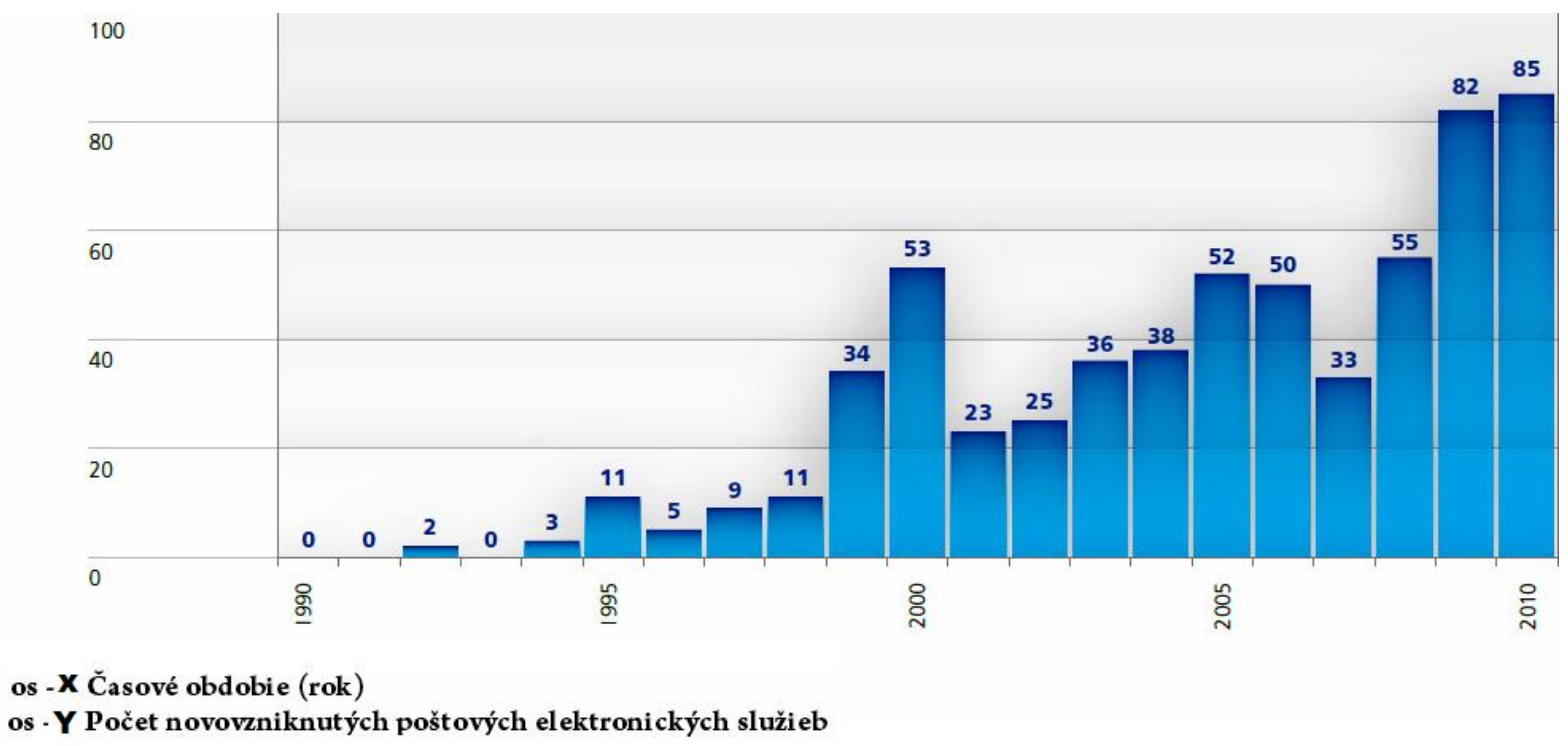

Obrázok 1. Počet zavedených poštových elektronických služieb každý rok na celom svete (Zdroj: Universal postal union. Measuring postal e-servicse development: a global perspecitve. 2012, [online]. [cit. 2012-10-19]. Dostupné na internete: <http://www.upu.int> Vlastné spracovanie)

\section{Záver}

Systematická implementácia poštových elektronických služieb umožňuje poštovému podniku pružnú adaptáciu na poštovom trhu, ktorej zámerom je maximalizácia spokojnosti zákazníka a schopnost' reagovat' na potreby a požiadavky trhu. V súčasnosti je vel'mi dôležité prispôsobit' sa nastoleným trendom v oblasti elektronizácie poštových služieb, pretože jedine tak môžu poštové podniky napredovat'.

\section{Literatúra}


[1] NEMČEK, B.: Substitúcia poštových zásielok a nové formy podnikania pre vybrané segmenty obchodných modelov (B2C): diplomová práca, vedúci DP: Ing. Rita Tornyaiová, KS. Žilina: 2012, 89s.

[2] Universal postal union. Measuring postal e-services development: a global perspective. 2012, [on-line]. [cit. 2012-10-11]. Dostupné na internete: <http://www.upu.int>

\section{Grantová podpora}

Príspevok vznikol za podpory nasledovných grantových projektov: VEGA 1/0199/11Výskum interoperability metód riadenia so strategickým zámerom organizácie a KEGA 052ŽU-4/2012 On-line riadenie výučby v procese vzdelávania voblasti informačnokomunikačných technológií. 